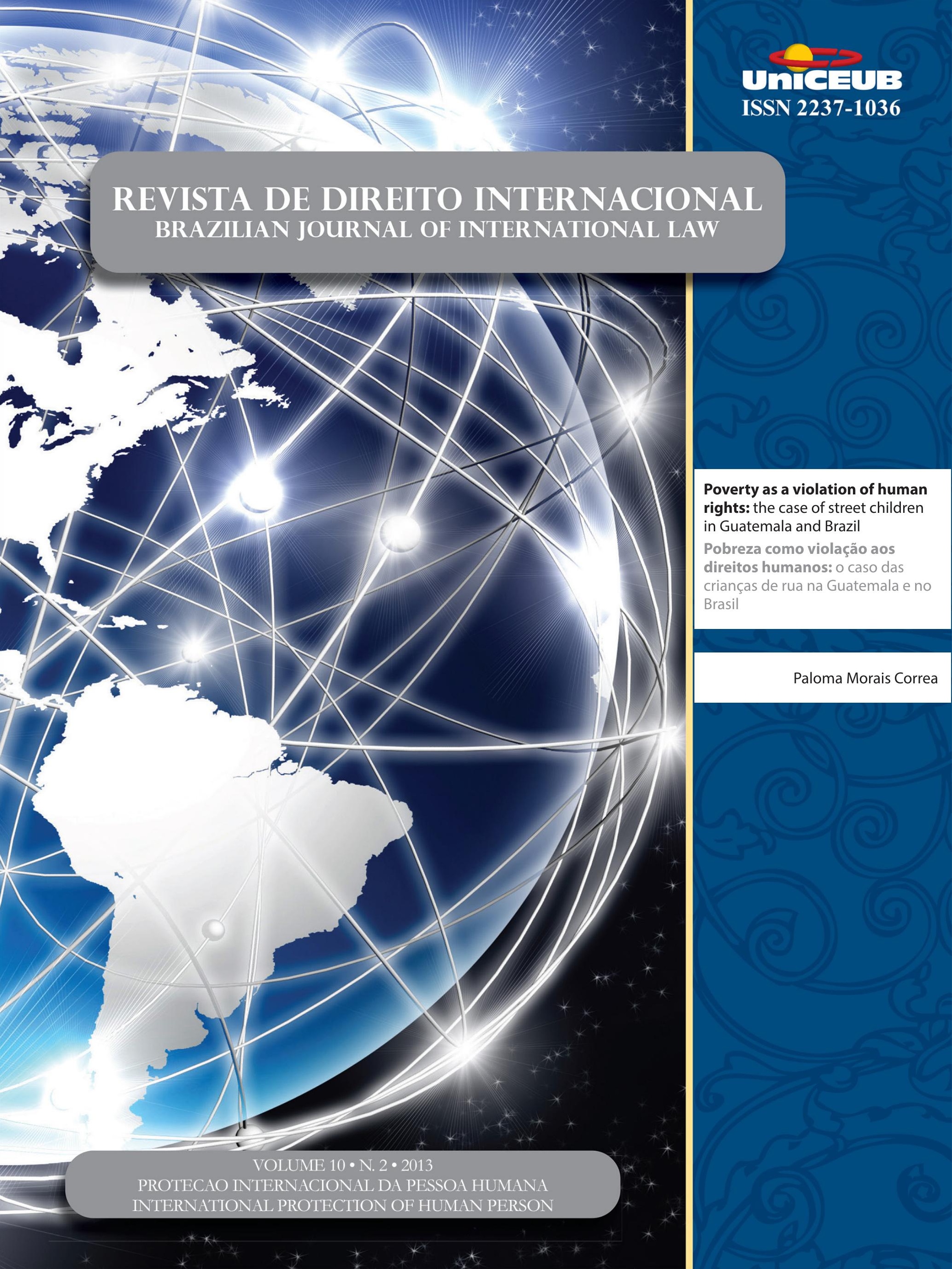




\section{Artigo Especial}

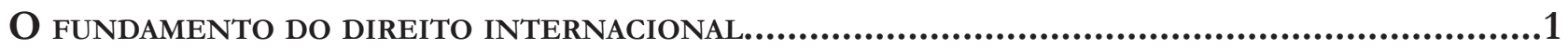
Alfred Verdross

\section{Proteção Internacional dos Direitos Humanos}

INDIGENOUS RIGHTS MOVEMENT: IS THE SAME NEEDED TO PREVENT CONTINUED HUMAN RIGHTS VIOLATIONS OF THE MENTALLY ILL

Liesel LeCates

O Discurso DAS DROGAS CONSTRUído PELO DIREITO INTERNACIONAL

Camila Soares Lippi

O ESTADO DEMOCRÁTICO DE DIREITO LAICO E A "NEUTRALIDADE" ANTE A INTOLERÂNCIA RELIGIOSA

Antonio Baptista Gonçalves

UM DiREITO SEM ESTADO? DiREITOS humanos E A FORMAÇÃo DE UM NOVO QUADRo NORMATIVO GLOBAL .87

Anderson Vichinkeski Teixeira e Rafael Köche

\section{Direito Humanitário}

The U.N. Standard Minimum Rules for the Treatment of Prisoners and North Korea: How North Korea is Violating these Rules with its Operation of the Yodok Concentration CAMP.

Tom Theodore Papain

U.S. Institutionalized Torture with Impunity: Examining Rape and Sexual Abuse in Custody Through the ICTY JurisprudenCE. 126 Allison Rogne 
Abduction, Torture, Interrogation: An Argument Against Extraordinary RendiTION

Kaitlyn E. Tucker

United States and European Union approaches to the death penalty: America SHOULD CONSIDER A NEW PERSPECTIVE 155 Katie R Hill

Tudo DE NOVO NO FRONT: MONUSCO, UMA NOVA ERA NAS PEACEKEEPING OPERATIONS? .169 Priscila Fett

A ADMINISTRAÇÃo DE TERRITÓRIOS OCUPADOS: INDETERMINAÇÃO DAS NORMAS DE DIREITO INTERNACIONAL HUMANITÁRIO?. 184 João Henrique Ribeiro Roriz, Fabia Fernandes Carvalho Veçoso e Lucas da Silva Tasquetto

THE (IN)APPLICABILITY OF THE STATUTE OF REFUGEES TO ENVIRONMENTALLY DISPLACED PERSONS 197 Maria Cláudia da Silva Antunes de Souza e Lucas de Melo Prado

\section{Sistema Interamericano de Direitos Humanos}

A contribuição da Comissão Interamericana de Direitos Humanos para o acesso À jus-

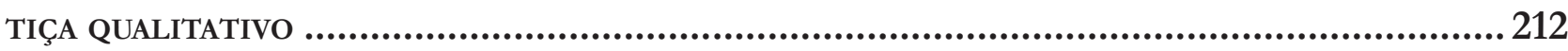
Márcio Antônio de Oliveira Filho, Ana Caroline Portes de Oliveira, Jéssica Galvão Chaves e Warlen Soares Teodoro

A executividade das sentenças da Corte Interamericana de Direitos Humanos no

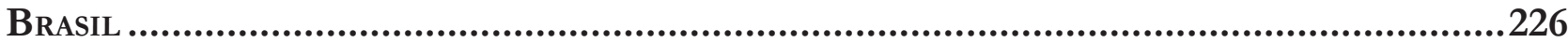

Augusto César Leite de Resende

A efetividade do ativismo jurídico transnacional no Sistema Interamericano de DiREITOS HuMANOS: UMA ANÁLISE A PARTIR DE CASOS CONTRA O BRASIL .................................238 Renata Mantovani de Lima e Lucélia de Sena Alves

O Processo e o Direito Coletivo no Sistema Interamericano de Direitos Humanos: UMA ANÁLISE COM BASE NA JURISPRUDÊNCIA INTERNACIONAL ...........................................250 Laercio Dias Franco Neto e Dafne Fernandez de Bastos 
CORTE INTERAMERICANA DE DIREITOS HUMANOS: OPINIÃo CONSULTIVA 4/84 - A MARGEM DE

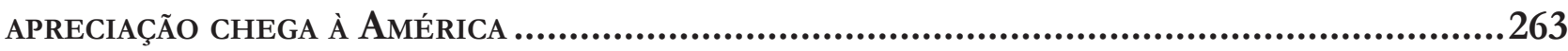

Paloma Morais Corrêa

A "PLENA" LIBERDADE DE EXPRESSÃo E OS DIREITOS HUMANOS: ANÁLISE DA JURISPRUDÊNCIA DA Corte InTeramericana de Direitos Humanos e o Julgamento da ADPF 130 281 Natália Paes Leme Machado

A proteção do meio ambiente no Sistema Interamericano de Direitos Humanos a parTIR DO DIREITO À EDUCAÇÃO.

Augusto César Leite de Resende

Parameters and procedures of the Inter-American System of Human Rights in CHILDREN'S RIGHTS VIOLATION LAWSUITS

Maria Guiomar da Cunha Frota e Pedro Alves Barbosa Neto

Poverty as a Violation of Human Rights: THE CASE OF STREET CHILDREN IN GUATEMALA AND BRAZIL

Paloma Morais Correa

\section{Proteção Internacional dos Direitos Humanos e o Direito Brasileiro}

A LEI N. 11.340/06 E SUAS REPERCuSSõES No CONTRATO INDIVIDUAL DE TRABALHo. Humberto Lima de Lucena Filho e Waldeny Pereira Filho

ORIENTAÇÃo SEXUAL E DISCRIMINAÇão NO AMBIENTE LABORAL

Glaucia Fernanda Oliveira Martins Batalha

NORMAS EDITORIAIS 


\title{
Poverty as a violation of human rights: the case of street children in Guatemala and Brazil
}

\author{
Pobreza como violação aos direitos \\ humanos: o caso das crianças de rua na \\ Guatemala e no Brasil*
}

Paloma Morais Correa**

The greatest misfortune of extreme poverty

is that for your entire existence you are like someone already dead.

Father Wresinski, 1989.

\section{Abstract}

Although human rights are officially regarded by the United Nations as indivisible, interrelated and interdependent, it is largely recognised the gap concerning mechanisms for adjudication between civil and political rights compared to economic, social and cultural ones. The very existence of an individual right not to be poor is still controversial within both - domestic and global societies. Consequently, the responsibility for providing individuals with rights such as food, water, shelter and education, although doubtless related to human dignity, have been constantly denied by states and by the international community. By analysing two cases of extrajudicial execution of street children in the American continent, this paper aims to address the debate of poverty as a violation of human rights considered as an option for judicial enforcement of economic, social and cultural rights. This article undertakes a qualitative analysis on jurisprudence, as well as literature and documents concerning the adjudication of such rights by the Inter-American Court. While taking an integrated approach to human rights, the links between poverty and vulnerability to other sorts of violations, such as urban violence, will be demonstrated. This paper will suggest that the adoption of the new Protocol to the International Covenant on Economic, Social and Cultural Rights (ICESCR) shall act as a supervisory mechanism to guaranteeing international implementation of social justice.

Keywords: Poverty. Human rights. Street children. Violence.

** Bacharel em Direito pela Universidade Federal do Rio Grande do Sul (2008), com intercâmbio de um semestre na Universidade de Westminster, Londres (2006). Mestre em Relações Internacionais pela Universidade Federal do Rio Grande do Sul (2010) e Mestre em Direitos Humanos pela London School of Economics and Political Science (2010). Advogada. Foi professora no curso de Relações Internacionais da Universidade Federal de Pelotas. Atualmente, é Analista Técnica de Políticas Sociais no Ministério do Desenvolvimento Social e combate à Fome. Email: palomamcorrea@hotmail.com

\section{Resumo}

Embora os direitos humanos sejam oficialmente reconhecidos pela Organização das Nações Unidas como indivisíveis, inter-relacionados e interdependentes, é visível a distância existente entre os mecanismos de responsabilização dos direitos civis e políticos em comparação com os dos direitos econômicos, sociais e culturais. A própria existência de um direito individual 
a não ser pobre ainda é controversa no interior das sociedades domésticas e na sociedade global. Consequentemente, a responsabilidade de prover os indivíduos com os direitos à alimentação, água, moradia e educação, embora inegavelmente relacionados à dignidade humana, têm sido constantemente negados tanto pelos estados quanto pela comunidade internacional. Através da análise de dois casos de execução extrajudicial de crianças de rua no continente Americano, este artigo considera o debate que classifica a pobreza como uma violação aos direitos humanos como uma opção para garantir a implementação de direitos econômicos, sociais e culturais. O estudo realiza uma análise qualitativa doutrinária, jurisprudencial e documental acerca das decisões da Corte Interamericana que responsabilizam os estados pela garantia desses direitos. Adotando um enfoque integrado de direitos humanos, os elos entre pobreza e vulnerabilidade a outras formas de violações, tais como a violência urbana, serão demonstrados. $\mathrm{O}$ artigo sugere que a adoção do novo Protocolo para o Pacto Internacional de Direitos Econômicos, Sociais e Culturais (PIDESC) atuará como um mecanismo de supervisão internacional na garantia da justiça social.

Palavras-chave: Pobreza. Direitos humanos. Crianças de rua. Violência.

\section{INTRODUCTION}

In 1992, the United Nations (UN) declared October the $17^{\text {th }}$ the International Day for the Eradication of Poverty $^{1}$, and the halving of poverty by 2015 was agreed by 149 countries to be the central objective of the UN Millennium Goals. ${ }^{2}$ From a human rights perspective, the suffering of people living on extreme poverty due to a lack of basic human needs such as food, water, housing and education violates the dignity of the person. However, the International Law of Human Rights does not offer to the economic, social and cultural rights the same sort of supervisory mechanisms of enforcement as to civil and political rights. In fact, the classification of poverty as a human rights violation is still largely debated. As a result, human miseries related to poverty

1 See: www.atd-uk.org/internationalday.htm

2 LADERCHI, Caterina Ruggeri, SAITH, Ruhi and STEWART, Frances. Does it Matter that we do not Agree on the Definition of Poverty? A Comparison of Four Approaches. Oxford Development Studies, 31:3, 243, 2003. tend to be seen as less important than violations of civil and political rights, such as torture, unlawful arrest or the cease of individual freedoms.

The adoption of an optional protocol to the International Covenant on Economic, Social and Cultural Rights (ICESCR) establishing an individual complaints procedure upon the UN Committee on Economic, Social and Cultural Rights (CESCR) might be seen as an attempt to approximate the two Covenants in terms of their mechanisms of adjudication. Nevertheless, the adoption of the protocol raised controversies among groups who advocate the unsuitableness of a petition procedure to claim social justice. By analysing two Inter-American case laws of extrajudicial execution of street children, this paper aims to address the subject of poverty as a violation of human rights and the advantages that the New Protocol might bring to this issue. Focusing on the reality of street children in countries such as Guatemala and Brazil, I aim to demonstrate how poverty leaves people vulnerable to violence, and therefore, to support the fundamental importance of enforcing economic, social and cultural rights as a tool to combating both - poverty and urban violence.

This paper briefly outlines different definitions of poverty according to the literature and some of the UN documents that express concern with the issue, as well as the responsibility of states in relation to poverty. Based on Reports from the Inter-American System of Human Rights and from Amnesty International, it draws on case studies on the situation of street children in Guatemala and Brazil, to argue that poverty leads to a vulnerability to other sorts of violations, such as police abuse. I will then consider the judicial enforcement of economic, social and cultural (ESC) rights and conclude by suggesting that the New Protocol to the ICESCR might advance the debate of poverty as a violation of human rights and therefore facilitate the implementation of social justice.

\section{Poverty as a Way Of LOOKIng at It:}

There is no single definition of poverty, since the term can be understood according to different interpretations on what constitutes a good life for individuals and a good society to live in. Laderchi and other authors suggest four different approaches to poverty, 
which are: the monetary approach, the capabilities approach, social exclusion and participatory approach. ${ }^{3}$ The monetary approach is the most commonly used, in both national and international spheres. It identifies poverty according to levels of consumption and income, calculated based on market prices, taking a poverty line as its basis. The monetary approach measures welfare as 'the total consumption enjoyed', defining poverty as 'a shortfall below some minimum level of resources, which is termed the poverty line. ${ }^{4}$

A second approach to poverty is the capability one, pioneered by Sen, to whom development could be defined as a 'process of expanding the real freedoms that people enjoy', and extreme poverty as an economic obstacle to freedom. ${ }^{5}$ Since the exercise of freedoms, according to Sen, was a necessary condition to lead the kind of lives we have reason to value', material goods represent a vehicle to facilitate the achievement of freedom. ${ }^{\circ}$ By emphasising the outcomes characterising the 'realization of human potential', the capabilities approach rejects utilitarianism as the measure of welfare, and considers the 'differences individuals face in transforming resources into valuable achievements', which explains why, according to this approach, monetary resources are a non-reliable source to indicate capability outcomes. ${ }^{7}$

Departing from the monetary and capabilities individualistic views of poverty, the social exclusion approach offers a socially constructed definition to it, taking into consideration social processes of marginalisation and deprivation. According to the social exclusion approach, there are 'structural characteristics of a population which are empirically correlated with multiple deprivations'. ${ }^{8}$ Socially excluded are, for example,

3 LADERCHI, Caterina Ruggeri, SAITH, Ruhi and STEWART, Frances. Does it Matter that we do not Agree on the Definition of Poverty? A Comparison of Four Approaches. Oxford Development Studies, 31:3, 243, 2003.

4 LADERCHI, Caterina Ruggeri, SAITH, Ruhi and STEWART, Frances. Does it Matter that we do not Agree on the Definition of Poverty? A Comparison of Four Approaches, Oxford Development Studies, 31:3, 243, 2003, at 248.

5 SEN, Amartya. Development as Freedom, Oxford: Oxford University Press, 1999, at. 3.

6 SEN, Amartya. Development as Freedom, Oxford: Oxford University Press, 1999, at 14.

7 LADERCHI, Caterina Ruggeri, SAITH, Ruhi and STEWART, Frances. Does it Matter that we do not Agree on the Definition of Poverty? A Comparison of Four Approaches, Oxford Development Studies, 31:3, 243, 2003, at 253.

8 LADERCHI, Caterina Ruggeri, SAITH, Ruhi and STEWART, Frances. Does it Matter that we do not Agree on the Definition the handicapped, drug users, delinquents and the aged.

The innovation brought by the participatory approach is that it 'takes into account the views of poor people themselves.' Chambers, who initiated this method, focused on asking poor people about the meaning and the magnitude of their reality of poverty. ${ }^{9}$ This study empirically concluded that different approaches to poverty require different policies in order to eradicate it. While the monetary approach would focus on the generation of financial incomes as the main policy to eradicate poverty, the capabilities approach would emphasise the social provision and allocation of goods, as well as giving importance to non-material values, such as political and cultural life. Redistributive and structural policies aiming at eliminating discrimination would get priority according to the social exclusion approach, whereas the empowerment of the poor to become the agent of his or her own rights would be the target to eliminate poverty for participatory policy-makers. ${ }^{10}$ The study revealed significant differences on the identification of poor people according to the four different approaches. These differences observed in the policy requirements to fight poverty, as well as the discrepancies on identifying who is and who is not poor in a certain society corroborates the final claim of Laderchi and others, that 'clearer and more transparent definitions of poverty are an essential prerequisite of any development policy that puts poverty reduction at its centre. ${ }^{31}$

\subsection{The United Nations view of poverty:}

Although assuming that there is no universally accepted definition of poverty, the Committee on Economic, Social and Cultural Rights (CESCR) endorses a multi-dimensional concept of poverty to define it as 'a complex state of material and non-material depriva-

of Poverty? A Comparison of Four Approaches, Oxford Development Studies, 31:3, 243, 2003, at 259.

9 LADERCHI, Caterina Ruggeri, SAITH, Ruhi and STEWART, Frances. Does it Matter that we do not Agree on the Definition of Poverty? A Comparison of Four Approaches, Oxford Development Studies, 31:3, 243, 2003, at 260.

10 LADERCHI, Caterina Ruggeri, SAITH, Ruhi and STEWART, Frances. Does it Matter that we do not Agree on the Definition of Poverty? A Comparison of Four Approaches, Oxford Development Studies, 31:3, 243, 2003, at 263-264.

11 LADERCHI, Caterina Ruggeri, SAITH, Ruhi and STEWART, Frances. Does it Matter that we do not Agree on the Definition of Poverty? A Comparison of Four Approaches, Oxford Development Studies, 31:3, 243, 2003, at 269. 
tions that leads the individual to exclusion. ${ }^{12}$ The term poverty is not explicitly written in the ICESCR, but the eradication of poverty is closely related to rights such as 'the right to work, to have an adequate standard of living, housing, food, health and education', all of which are the Covenant's main concern. ${ }^{13}$

The UN Millennium Development Goals 2008 includes among the consequences of poverty the exposure to violence, and stresses the view that 'human rights violations are both a cause and a consequence of poverty. ${ }^{14}$

Poverty results from disempowerment and exclusion. Poverty is not simply a lack of material goods and opportunities such as employment, ownership of productive assets and savings. It is also the lack of physical and social goods, such as health, physical integrity, freedom from fear and violence, social belonging, cultural identity, organizational capacity, the ability to exert political influence, and the ability to live in respect and dignity. ${ }^{15}$

In its statement on poverty, the CESCR visualised poverty as a 'denial of human rights'. ${ }^{16}$ Academic studies in the area of development, however, lead to the acceptance, nowadays, of poverty as a violation of human rights ${ }^{17}$, and Campbell identifies that the violation might not be related to the causation of harm itself, but in 'the failure to act so as to enable those who are in extreme poverty to escape from that condition. ${ }^{18}$ In this sense, Upendra Baxi reflects on the existence of a dignity common to bearers of human rights, which allows them to be and remain human. Following the author's reasoning, the right to be and remain human is the very meaning of the concept of development, and in relation to the phenomenon of poverty, 'total and continuing destitution and impoverishment exposes

12 CESCR. Statement on Poverty and the ICESCR. 25th sess., at 1, U.N. Doc. E/C.12/2001/10, 2001.

13 CESCR. Statement on Poverty and the ICESCR. 25th sess., at 1, U.N. Doc. E/C.12/2001/10, 2001.

14 UNHCHR. Claiming the Millenium Development Goals: A Human Rights Approach, 2008, at 7.

15 UNHCHR. Claiming the Millenium Development Goals: A Human Rights Approach, 2008, at 7.

16 UNHCHR. Claiming the Millenium Development Goals: A Human Rights Approach, 2008, at 1.

17 The ATD Fourth World, a NGO founded in 1957 by Father Wresinski, has based its work on the view that extreme poverty is a violation of human rights. See: http://www.atd-uk.org/, last visited Aug. 9, 2010.

18 STEINER, Henry, ALSTON, Philip and GODMAN, Ryan. International Human Rights in Context: Law, Politics and Morals. 3rd edition. Oxford: Oxford University Press, 2008, at 3. people to a loss of their humanity.19 A question proposed by Baxi contributes to the understanding of poverty as a violation of human rights - rather than a denial - as suggested by the CESCR. According to Baxi, the 'violation of the impoverished to remain human' must be classified as violence for the same reason that the 'violation of some people's rights is called violence'. ${ }^{20}$

The issues of poverty and development are not new in the United Nations agenda. The text of the Declaration of Cocoyoc, presented by two bodies of the UN in Mexico in 1974, assumed that 'more people were hungry, sick, shelterless and illiterate that day than when the UN was first set up. ${ }^{21}$ The document also admitted that "the failure of a world society to provide "a safe and happy life" for all was not caused by any lack of physical resources, but by economic and social maldistribution and misuse. ${ }^{22}$ The first concern expressed in the Declaration was to redefine the purpose of development, which should focus on the development of human beings rather than of any material goods. ${ }^{23}$ As a result, the Declaration of Cocoyoc recognised that human beings have basic needs, such as food, shelter, clothing, health, education, and that economic growth should firstly focus on the improvement of such conditions for the poorest sections of the global society. In addition, the text of the Declaration emphasised the non-material aspects of development, such as the right to professional self-realisation. ${ }^{24}$

In 1987, the UN adopted the Limburg Principles on the implementation of the ICESCR, to consider the nature and scope of States parties' obligations regarding the Covenant and to issue interpretative principles in relation to the provisions stated in Parts II and III of the Covenant. The violations of ESC rights, the reporting

19 BAXI, Upendra. From human rights to the right to be human: some heresies. Ind. Int'l. Q., 1986, at. 187.

20 BAXI, Upendra. From human rights to the right to be human: some heresies. Ind. Int'l. Q., 1986, at 197.

21 The Cocoyoc Declaration, International Organization, vol. 29, n. 3, 893. International Responses to Technology, University of Wisconsin Press, summer 1975, available at http://websie.eclac.cl/ $\mathrm{mmp} /$ doc/Cocoyocdeclaration1974.pdf.

22 The Cocoyoc Declaration, International Organization, vol. 29, n. 3, 893. International Responses to Technology, University of Wisconsin Press, summer 1975, at 894.

23 The Cocoyoc Declaration, International Organization, vol. 29, n. 3, 893. International Responses to Technology, University of Wisconsin Press, summer 1975, at 896.

24 The Cocoyoc Declaration, International Organization, vol. 29, n. 3, 893. International Responses to Technology, University of Wisconsin Press, summer 1975, at, at 896-897. 
procedure and the international cooperation under Part IV of the Covenant, as well as the role of the Committee were also object of concern for the drafters of the Limburg Principles. ${ }^{25}$

The Maastricht Guidelines on violations of economic, social and cultural rights, adopted by the UN in celebration of the tenth anniversary of the Limburg Principles, examined once again the States obligations in the light of the ICESCR. It reinforced the view that 'it is no longer taken for granted that the realization of ESC rights depends significantly on action by the State, although, as a matter of International Law, the State remains ultimately responsible for guaranteeing the realization of these rights. ${ }^{26}$ Stressing the nature of the obligations to respect, protect and fulfil, and in accordance to the General Comment No.3 of the CESCR, the Maastricht guidelines further acknowledges that 'a State party in which any significant number of individuals is deprived of essential foodstuffs, of essential primary health care, of basic shelter and housing, or of the most basic forms of education is, prima facie, violating the Covenant. ${ }^{27}$ In addition, and clearly encouraging the adoption of an Optional Protocol to the ICESCR, the UN document states that 'victims of violations of ESC rights should have access to judicial or other appropriate remedies at both national and international levels. ${ }^{28}$

\section{THE VULNERABILITY OF STREET CHILDREN - THE CASES OF Guatemala AND Brazil:}

Brazil and Guatemala ratified the United Nations Convention on the Rights of the Child in $1990 .{ }^{29}$ In the same year, Amnesty International published a Special Report on Guatemala concerning the issue of extraju-

25 Limburg Principles on the Implementation of the ICESCR. Human Rights Quarterly, 9, 1987, at 122-135.

26 CESCR. The Maastricht Guidelines on Violations of Economic, Social and Cultural Rights. 24 ${ }^{\text {th }}$ Sess., U.N. Doc. E/C.12/2000/13, 2010, at 16.

27 CESCR. The Maastricht Guidelines on Violations of Economic, Social and Cultural Rights. 24 ${ }^{\text {th }}$ Sess., U.N. Doc. E/C.12/2000/13, 2010, at 18.

28 CESCR. The Maastricht Guidelines on Violations of Economic, Social and Cultural Rights. 24 ${ }^{\text {th }}$ Sess., U.N. Doc. E/C.12/2000/13, 2010, at 22.

29 Available at: http://Treaties.un.org/Pages/ViewDetails, last visited July 26, 2010. dicial executions and human rights violations against street children. ${ }^{30}$ In August 1990, the Amnesty International Newsletter reported that, according to Guatemalan sources, there were 5000 children, aged five to eighteen, living on the streets of Guatemala City. Even more disturbing were reports of human rights abuses carried out against such children by Guatemala City police, such as threats, beatings, torture and extrajudicial executions. ${ }^{31}$ A month later, in September 1990, Amnesty International denounced several cases of torture and extrajudicial executions of children and adolescents who lived in the streets of Brazil. Similar to the Guatemalan case, the perpetrators were police officers, acting in groups known as 'death squads'. ${ }^{32}$ According to the Inter-American Commission on Human Rights (IACHR) Report, issued in 1997, it was estimated that 30 000 children lived daily on the streets of Rio de Janeiro, 1000 of whom also slept on the streets. In São Paulo, it was believed that 20000 children spent their days on the streets. ${ }^{33}$ These children depend on activities such as begging, theft, prostitution and informal street trading to survive. An Inter-Non-governmental Organisation (NGO) Program on Street Children and Street Youth proposed a definition for the term of street children, and according to it, 'a street child or street youth is any minor for whom the street (in the widest sense of the word including unoccupied dwellings, waste land etc) has become his or her habitual abode, and who is without adequate protection. ${ }^{34}$

Street living children have often been abandoned, are orphans, or have been sent away from home. There are also those who have run away from domestic violence, and that go to the streets looking for what are a child immediate needs anywhere in the world: food, shelter and company. ${ }^{35}$ Although there are several different reasons for a child to make the streets of big cities

30 Amnesty Int'l. Guatemala: extrajudicial executions and human rights violations against street children. London: International Secretariat, July 1990.

31 Amnesty Int'l Newsletter. Guatemala: children abused by police, Vol. XX, N. 8, Aug. 1990.

32 Amnesty Int'l Newsletter. Brazil: Child victims of killing and cruelty, Vol. XX, N. 9, Sep. 1990.

33 IACHR. Report on the situation of Human Rights in Brazil. Chapter V: Violence against minors. Sep. 29, 1997, available at: http://www. cidh.oas.org/countryrep/brazil-eng/chaper $\% 205 \% 20$.htm, last visited July 8, 2010.

34 Amnesty Int'l Campaign Journal UK. On the streets, Issue 94, (March/April 1999), at 5.

35 Amnesty Int'l Campaign Journal UK. On the streets, Issue 94, (March/April 1999), at 6. 
his or her home, there is a background feature which is, according to Amnesty International research, common to all of them: 'family stress and breakdown through poverty, armed conflict, natural disaster or disease'. ${ }^{36}$ In the cases of Latin American countries such as Guatemala and Brazil nowadays, poverty can be regarded as the common pattern among street children. According to Amnesty International, street children are 'especially vulnerable to abuse of their rights', firstly because they have little access to basic rights such as health care, education and leisure, and secondly, because 'their poverty brings them into the path of the law'. ${ }^{37}$ Therefore, the reality of children who are forced to live on the streets is of vulnerability to human rights abuses such as arbitrary arrest and ill-treatment.

Police violence against street children is often related to a context of ill public security, where increasing crime rates scary society in general. As a result, it is observed a public support for violent police action in order to control crime. ${ }^{38}$ It is such context that gives origin to the so called 'death squads', which are groups comprised of off-duty police officers whose task is to kill people that society considers undesirable, such as street children. ${ }^{39}$ In reference to the case of Brazil, Amnesty International pointed out that 'the mere fact of being on the streets, ill-clothed and ill-fed, makes such children suspected criminals in the eyes of many civil and military police officers, and therefore vulnerable to arbitrary treatment. ${ }^{30}$

Although it did not mention specifically the case of street children, the Amnesty International Report 2010 expressed concern with the continuous cases of police violence in both Brazil and Guatemala. In relation to Brazil, the newest Report issued by Amnesty International revealed that ' $(. .$.$) law enforcement officers conti-$ nued to use excessive force and to carry out extrajudicial executions and torture with impunity (...) numerous law enforcement officials were charged with involvement in organized crime and death squads. ${ }^{31}$ Referring

36 Amnesty Int'l Campaign Journal UK. On the streets, Issue 94, (March/April 1999), at 5.

37 Amnesty Int'l Campaign Journal UK. On the streets, Issue 94, (March/April 1999), at 6.

38 Amnesty Int'l. Guatemala: extrajudicial executions and buman rights violations against street children. London: International Secretariat, July 1990 , at 1.

39 Amnesty Int'l Campaign Journal UK. On the streets. Issue 94, (March/April 1999), at 6.

40 Amnesty Int'l Newsletter. Brazil: Child victims of killing and cruelty. Vol. XX, N. 9 (Sep. 1990), at 3.

41 Amnesty Int'l Report 2010. Available at http://therereport.am- to Guatemala, Amnesty International cited the report of the UN Special Rapporteur on extrajudicial, summary of arbitrary executions to affirm the 'persistence of executions of gang members of criminal suspects'. The same report denounced that 'local organizations had found evidence of the continued involvement (...) of members of the police force in these killings ${ }^{42}$ For the last years, Human Rights Watch has also investigated Brazilian and Guatemalan cases of police violence. ${ }^{43}$

\subsection{Guatemala - the I/A court H.R. "Street Chil- dren" case:}

The Villagran-Morales et al. $v$ Guatemala case was submitted to the Inter-American Court of Human Rights (I/A Court H.R) by the Inter-American Commission on $\mathrm{Hu}-$ man Rights following a petition received in September 1994. The case concerned the kidnapping, torture and murder of four youths who were known in the region as they used to live in the streets of an area called 'Las Casetas', in Guatemala City. The victims were aged 15-20 and were reportedly forced into a truck by four armed gunned men on the afternoon of 15 June 1990. Their bodies were later found showing signs of torture and gunshots wounds. A few days later, a 17-year-old adolescent was shot dead in the same place. According to the Inter-American Commission, the aforementioned place was 'recognised as an area with a high delinquency and crime rate ${ }^{44}$, and witnesses have appointed that the murderers were members of the Fifth National Police Corps. In the domestic proceedings held in the Guatemalan Courts, the accused were acquitted for lack of evidences.

According to the petition submitted by the Commission, it was for the Inter-American Court to evaluate on the violation of articles one, four, five, seven, eight, 19 and 25 of the American Convention by the state of Guatemala. By these articles, the American Convention

nesty.org, last visited Aug. 3, 2010.

42 Amnesty Int'l Report 2010. Available at http://therereport. amnesty.org, last visited Aug. 3, 2010, at 155.

43 See: Human Rights Watch. Brazil: Curb Police Violence in Rio, São Paulo: extrajudicial killings undermine public security. Dec. 8, 2009, available at www.hrw.org/americas/brazil, last visited Aug. 3, 2010. Human Rights Watch. Universal Periodic Review of Guatemala: Police abuses, May 4, 2008, available at www.hrw.org/americas/guatemala, last visited Aug. 3, 2010.

44 I/A Court H.R. "Case of the Street Children" Villagran-Morales and others $v$ Guatemala. Preliminary Objections. Series C N. 32, 4 (Sep. 11, 1997), available at www.corteidh.or.cr/docs/casos/articulos/series_32_ing.doc, last visited Nov. 14, 2009. 
codifies the states obligation to respect rights, offering protection on the rights to life, humane treatment, personal liberty, fair trial, the rights of the child and the right to judicial protection. Concerning the impunity that followed the investigation of the case, the Commission supported the view that 'justice has been denied in the pertinent domestic procedures'. ${ }^{45}$ Therefore, the Inter-American Court should decide upon 'the failure of the State mechanisms to deal (appropriately) with human rights violations to the American Convention, and afford the victims' families access to justice', ${ }^{46}$

In the procedures that followed before the Inter-American Court, documentary and testimonial evidences were presented. According to the mother of one of the victims, her son 'used to consume drugs and alcohol and had been arrested on several occasions for vagrancy on the streets' ${ }^{47}$ During the trial, one of the witnesses, who used to be a street child, declared that she was afraid of the police because they used to threaten street children, often saying that 'as they were good for nothing, they would be better dead'. ${ }^{48}$ In reference to an Amnesty International Report on street children in Guatemala, published in 1990, the Court stated as proven the fact that:

In Guatemala, at the time the events occurred, there was a common pattern of illegal acts perpetrated by State security agents against "street children"; this practice included threats, arrests, cruel, inhuman and degrading treatment and homicides as a measure to counter juvenile delinquency and vagrancy. ${ }^{49}$

When submitting the case to the Court, the Inter-American Commission stressed, in its final arguments,

45 I/A Court H.R. "Case of the Street Children" Villagran -Morales and others $v$ Guatemala, Preliminary Objections. Series C N. 32, 4, Sep. 11, 1997, available at www.corteidh.or.cr/docs/casos/articulos/series_32_ing.doc, last visited Nov. 14, 2009, at 6 .

46 I/A Court H.R. "Case of the Street Children" Villagran-Morales and others $v$ Guatemala, Preliminary Objections. Series C N. 32, 4, Sep. 11, 1997, available at www.corteidh.or.cr/docs/casos/articulos/series_32_ing.doc, last visited Nov. 14, 2009, at 2.

47 I/A Court H.R. "Case of the Street Children" Villagran -Morales and others $v$ Guatemala, Merits, Series C N.63, 13, Nov. 19, 1999, available at www.corteidh.or.cr/docs/casos/articulos/seriec_63_ ing.pdf, last visited July. 21, 2010.

48 I/A Court H.R. "Case of the Street Children" Villagran-Morales and others v Guatemala, Merits, Series C N.63, 13, Nov. 19, 1999, available at www.corteidh.or.cr/docs/casos/articulos/seriec_63_ ing.pdf, last visited July. 21, 2010, at16.

49 I/A Court H.R. "Case of the Street Children" Villagran -Morales and others v Guatemala, Merits, Series C N.63, 13, Nov. 19, 1999, available at www.corteidh.or.cr/docs/casos/articulos/seriec_63_ ing.pdf , last visited July. 21, 2010, at 25. the ius cogens nature of the right to life, maintaining that it required not only negative obligations from the state, but also the taking of positive measures to protect and preserve the right to life. The Commission then concluded that, in this particular case, the state of Guatemala had violated two aspects of the right to life. Furthermore, the impunity frequently afforded by the state agents who were responsible for these violations 'allowed and encouraged' this kind of violence against street children, consequently increasing their vulnerability. ${ }^{50}$

In reference to the violation to the right to life, the Inter-American Court stated that: 'the fundamental right to life includes, not only the right of every human being not to be deprived of his life arbitrarily, but also the right that he will not be prevented from having access to the conditions that guarantee a dignified existence. ${ }^{51}$ Considering the violation to the right to humane treatment, the Court supported the view that the circumstances surrounding the deaths caused extreme 'anxiety and suffering', not only for the victims themselves, who had been objects of physical and psychological abuse, but also for their families, who had been left without information on what had actually happened. ${ }^{52}$ Regarding the violation to the rights of the child, the Court reported 'the pattern of violence against street children in Guatemala at the time the facts occurred', which lead to 'a situation of abandonment and social exclusion' which were contrary to the rights of the child. ${ }^{53}$ Regarding the state obligations in relation to the rights of the child, the Inter-American Commission affirmed that:

It arose from the vulnerability of children and their
incapacity to personally ensure the respect of their
rights. It also declared that while the consequent
protection responsibilities correspond to the family
in principle, State measures are necessary in the case
of at risk children. According to the Commission,

50 I/A Court H.R. "Case of the Street Children" Villagran -Morales and others $v$ Guatemala, Merits, Series C N.63, 13, Nov. 19, 1999, available at www.corteidh.or.cr/docs/casos/articulos/seriec_63_ ing.pdf, last visited July. 21, 2010, at 36.

51 I/A Court H.R. "Case of the Street Children" Villagran -Morales and others v Guatemala, Merits, Series C N.63, 13, Nov. 19, 1999, available at www.corteidh.or.cr/docs/casos/articulos/seriec_63_ ing.pdf, last visited July. 21, 2010, at 37.

52 I/A Court H.R. "Case of the Street Children" Villagran -Morales and others v Guatemala, Merits, Series C N.63, 13, Nov. 19, 1999, available at www.corteidh.or.cr/docs/casos/articulos/seriec_63_ ing.pdf, last visited July. 21, 2010), at 38.

53 I/A Court H.R. "Case of the Street Children" Villagran -Morales and others v Guatemala, Merits, Series C N.63, 13, Nov. 19, 1999, available at www.corteidh.or.cr/docs/casos/articulos/seriec_63_ ing.pdf, last visited July. 21, 2010), at 44-45. 
this special State obligation encompasses the protection of a wide range of social, economic, civil and political interests of the child..$^{54}$

When States violate the rights of at-risk children, such as "street children", in this way, it makes them victims of a double aggression. First, such States do not prevent them from living in misery, thus depriving them of the minimum conditions for a dignified life and preventing them from the "full and harmonious development of their personality", even though every child has the right to harbor a project of life that should be tended and encouraged by the public authorities so that it may develop this project for its personal benefit and that of the society to which it belongs. Second, they violate their physical, mental and moral integrity and even their lives. ${ }^{55}$

Eventually, the Court also decided that the state of Guatemala had violated the rights to personal liberty, judicial protection and fair trial, as well as the obligation to prevent and punish torture. ${ }^{56}$

The kidnapping and extrajudicial execution of these street children were fully denounced by the 1990 Amnesty International report on Guatemala, as well as several other cases of human rights violations committed by police against street children in this country. Amnesty International also noted the failures on the investigations of the crimes, observing that the police report of the finding of the bodies of the victims did not mention the "clear marks of torture (...) which were visible in the police photographs taken of them after death. ${ }^{57}$ This demonstrates a pattern of impunity, which is also observed in cases such as these, and Amnesty International contended that "failure by the authorities to identify the perpetrators and bring them to justice could serve to encourage further such abuses. ${ }^{, 58}$

54 I/A Court H.R. "Case of the Street Children" Villagran -Morales and others v Guatemala, Merits, Series C N.63, 13, Nov. 19, 1999, available at www.corteidh.or.cr/docs/casos/articulos/seriec_63_ ing.pdf, last visited July. 21, 2010, at 45.

55 I/A Court H.R. "Case of the Street Children" Villagran -Morales and others $v$ Guatemala, Merits, Series C N.63, 13, Nov. 19, 1999, available at www.corteidh.or.cr/docs/casos/articulos/seriec_63_ ing.pdf, last visited July. 21, 2010, at 46.

56 I/A Court H.R. "Case of the Street Children" Villagran -Morales and others $v$ Guatemala, Merits, Series C N.63, 13, Nov. 19, 1999, available at www.corteidh.or.cr/docs/casos/articulos/seriec_63_ ing.pdf, last visited July. 21, 2010, at 59.

57 Amnesty Int'l. Guatemala: extrajudicial executions and buman rights violations against street children. London: International Secretariat, July 1990 , at 24 .

58 Amnesty Int'l. Guatemala: extrajudicial executions and buman rights violations against street children. London: International Secretariat, July 1990 , at 1 .

\subsection{The concurring opinion of judges Cançado Trindade and Abreu Burelli:}

In this judgment of the Inter-American Court of Human Rights, judges Cançado Trindade and Abreu Burelli delivered a concurring opinion where they firstly visualised the situation exemplified by the case, 'that of the suffering of the children in the streets, which affects a particularly vulnerable sector of the population of the countries of Latin America'. ${ }^{59}$ Then the judges went further to reinstate the Court's argument, while affirming:

The duty of the State to take positive measures is
stressed precisely in relation to the protection of life
of vulnerable and defenceless persons, in situation
of risk, such as the children in the streets. The
arbitrary deprivation of life is not limited, thus, to
the illicit act of homicide; it extends itself likewise
to the deprivation of the right to live with dignity.

Therefore, apart from basing the judgment in the conviction of the police agents of the State, stress is given to the fact that Guatemala had failed even before the murders. When stressing that 'there are distinct ways to deprive a person arbitrarily of life', the Inter-American judges interpreted the right to life as encompassing not only civil and political rights, but also economic, social and cultural rights, hence reaffirming the 'interrelation and indivisibility of all human rights' ${ }^{61}$ In relation to the case of street children in Latin America, therefore, it must be emphasised that 'the right to existence comprises conditions of life with dignity, security and integrity of the human person'. ${ }^{62}$ The sad conclusion expressed in this judgment was that these rights had been constan-

59 I/A Court H.R. Case of the "Street Children" Villagran -Morales and others $v$ Guatemala, Concurring Opinion of Judges Cançado Trindade and Abreu Burelli, Series C N. 63, 1, Nov. 19, 1999 , available at www.corteidh.or.cr/docs/casos/votos/vsc_cancadoabreu_63_ing.doc, last visited Nov. 14, 2009.

60 I/A Court H.R. Case of the "Street Children" Villagran-Morales and others $v$ Guatemala, Concurring Opinion of Judges Cançado Trindade and Abreu Burelli, Series C N. 63, 1, Nov. 19, 1999, available at www.corteidh.or.cr/docs/casos/votos/vsc_cancadoabreu_63_ing.doc, last visited Nov. 14, 2009, at 1-2.

61 I/A Court H.R. Case of the "Street Children" Villagran -Morales and others v Guatemala, Concurring Opinion of Judges Cançado Trindade and Abreu Burelli, Series C N. 63, 1, Nov. 19, 1999, available at www.corteidh.or.cr/docs/casos/votos/vsc_cancadoabreu_63_ing.doc, last visited Nov. 14, 2009, at 2.

62 I/A Court H.R. Case of the "Street Children" Villagran -Morales and others $v$ Guatemala, Concurring Opinion of Judges Cançado Trindade and Abreu Burelli, Series C N. 63, 1, Nov. 19, 1999, available at www.corteidh.or.cr/docs/casos/votos/vsc_cancadoabreu_63_ing.doc, last visited Nov. 14, 2009, at 2. 
tly denied to street children, and that this situation of exclusion and vulnerability could be observed for much time before their tragic deaths.

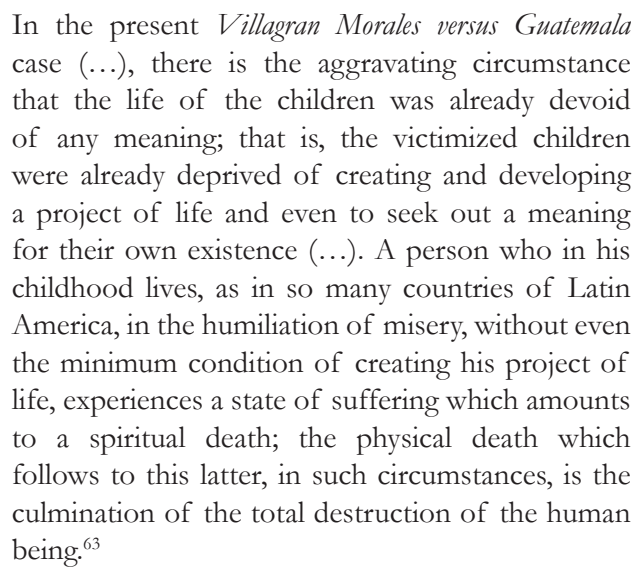

The judges went on to refer to the state of abandonment commonly faced not only by street children, but also by the members of their families, who are generally excluded from any social investment. ${ }^{64}$

The decision of the Inter-American Court in the street children case strongly supports the view that the evolution of the International Law of Human Rights approximates considerations of juridical and moral order. According to the concurring opinion highlighted above, moral claims belong to 'an order of superior values which are the substratum of legal norms'. ${ }^{65}$ This interpretation leads to reflexions on the 'meaning of the existence and of the destiny of each human being ${ }^{66}$ to the centre of the juridical debate on human rights. Hence, concepts of happiness and love achieve a paramount importance as the necessary conditions to the fully de-

63 I/A Court H.R. Case of the "Street Children" Villagran-Morales and others $v$ Guatemala, Concurring Opinion of Judges Cançado Trindade and Abreu Burelli, , Series C N. 63, 1, Nov. 19, 1999, available at www.corteidh.or.cr/docs/casos/votos/vsc_cancadoabreu_63_ing.doc, last visited Nov. 14, 2009, at 3.

64 I/A Court H.R. Case of the "Street Children" Villagran -Morales and others $v$ Guatemala, Concurring Opinion of Judges Cançado Trindade and Abreu Burelli, , Series C N. 63, 1, Nov. 19, 1999, available at www.corteidh.or.cr/docs/casos/votos/vsc_cancadoabreu_63_ing.doc, last visited Nov. 14, 2009, at 3.

65 I/A Court H.R. Case of the "Street Children" Villagran-Morales and others $v$ Guatemala, Concurring Opinion of Judges Cançado Trindade and Abreu Burelli, , Series C N. 63, 1, Nov. 19, 1999, available at www.corteidh.or.cr/docs/casos/votos/vsc_cancadoabreu_63_ing.doc, last visited Nov. 14, 2009, at 3.

66 I/A Court H.R. Case of the "Street Children" Villagran -Morales and others $v$ Guatemala, Concurring Opinion of Judges Cançado Trindade and Abreu Burelli, Series C N. 63, 1, Nov. 19, 1999, available at www.corteidh.or.cr/docs/casos/votos/vsc_cancadoabreu_63_ing.doc, last visited Nov. 14, 2009, at 3. velopment of every human being that the International Law of Human Rights cannot take for granted.

\subsection{Brazil - the "Candelária Church" case:}

In the biggest cities of Brazil, there are many places that are commonly used by street children as shelters. The large path located in front of Candelária Church, in the centre of Rio de Janeiro, was one of such places. On 23 July 1993, at the very early morning, two vehicles approximated Candelária Church, and gunned men opened fire against the children who were still asleep. Four of the children were killed instantly, many more were wounded and some of them died later on. ${ }^{67}$ This fact is internationally known as 'Candelária massacre', and according to the Council on Hemispheric Affairs (COHA), 'it became a symbol for children's rights, not only in Brazil, but throughout the world, especially where injustice and neglect leave abandoned children to fend for themselves. ${ }^{68}$

By 1997, after gross international campaign from $\mathrm{Hu}-$ man Rights Organisations such as Amnesty International and United Nations Children's Fund (UNICEF), nine men were brought to justice linked to the shootings, most of whom were police officers. Three officers were found guilty of participating in the atrocity, two were acquitted together with one civilian, two officers were released without being charged, and one was shot dead before going on trial. ${ }^{69}$ The tragic event can be remembered nowadays by anyone who passes through the sidewalk in front of the church in Rio de Janeiro, where an outline of eight infant bodies was painted on the floor in memory of the victims.

This massacre gave rise to a further investigation on death squadrons in Brazil. According to the 1997 Inter-American Report, the death or extermination squads were firstly established around 1950. Composed by police officers who were off-duty or who had been expe-

67 IACHR. Report on the situation of Human Rights in Brazil. Chapter V: Violence against minors, Sep. 29, 1997, available at: http://www. cidh.oas.org/countryrep/brazil-eng/chaper $\% 205 \% 20$.htm, last visited July 8, 2010.

68 The Council on Hemispheric Affairs (COHA). 16 Years After Candelária Massacre Impunity and Death Squads Still Roam Brazil Streets. COHA's Research Associate Leonardo Faria Chusán, July 24, 2009, available at www.coha.org, last visited July 8, 2010.

69 The Council on Hemispheric Affairs (COHA). 16 Years After Candelária Massacre Impunity and Death Squads Still Roam Brazil Streets, COHA's Research Associate Leonardo Faria Chusán, July 24, 2009, available at www.coha.org, last visited July 8, 2010. 
lled from the force due to their criminal activity, or by members of criminal organisations involved in illicit activities, commonly drug trafficking, the main duty of death squads is to guarantee the safety of persons living and working in a particular area. The main reason for what these officers join such groups, is the desire to increase their means of income. The Report also affirmed that in some cases, links between these criminals and local politicians have been investigated and proved as a method used to obtain votes and intimidate opponents. It was recorded that, between the years of 1991 and 1993, a number of thirty-one community leaders were executed by death squads in Rio de Janeiro. These squads usually operate with impunity, because police authorities and part of the public support their activities as a way to 'compensate for the inefficiency of the Judiciary in combating violence. ${ }^{70}$ As pointed out by Leonardo Chusán, research associate for the Council on Hemispheric Affairs,

\begin{abstract}
The combination of off-duty officers in search of extra income and wealthy citizens willing to pay to have their lifestyles and investments protected ultimately produces the emergence and acceptability of death squads.

The impunity in the Brazilian legal system, specifically as it affects the police force, encourages the constant violation of street children's human rights. Death squads remain in existence because of the disenchantment with the proper functioning of the legal system. ${ }^{71}$
\end{abstract}

The same report concludes that 'street children became the targets of these death squads because shopkeepers and wealthy citizens view them as threats to the public safety and commerce'.$^{72}$ Statistics shown that during the year of 1992, 424 children were victims of homicide in Rio de Janeiro and that another 229 were victims of homicide during the first six months of $1993 .{ }^{73}$ Victims of poverty, street children and adolescents are conside-

70 IACHR. Report on the situation of Human Rights in Brazil. Chapter III: Police violence and impunity, Sep. 29, 1997, available at http://www. cidh.oas.org/countryrep/brazil-eng/chaper\%203.htm, last visited July 8, 2010.

71 The Council on Hemispheric Affairs (COHA). 16 Years After Candelária Massacre Impunity and Death Squads Still Roam Brazil Streets, COHA’s Research Associate Leonardo Faria Chusán, July 24, 2009, available at www.coha.org, last visited July 8, 2010.

72 The Council on Hemispheric Affairs (COHA). 16 Years After Candelária Massacre Impunity and Death Squads Still Roam Brazil Streets, COHA’s Research Associate Leonardo Faria Chusán, July 24, 2009, available at www.coha.org, last visited July 8, 2010.

73 IACHR. Report on the situation of Human Rights in Brazil. Chapter V: Violence against minors, Sep. 29, 1997, available at: http://www. cidh.oas.org/countryrep/brazil-eng/chaper\%205\%20.htm, last visited July 8, 2010. red a threat to society. 'At times they make deals with the police or with organized crime and are executed extrajudicially when these deals fail'. ${ }^{74}$ Apparently, a failure on a drug-trade between victims and perpetrators was behind the motivation for the Candelária massacre.

The main causes of violence against street children and adolescents highlighted by the Inter-American Commission Report were: 'the dramatic socioeconomic conditions in the peripheral areas of the large urban centres', associated to 'the limited role of schools in combating violence' and the lack of assistance offered to minors who have committed crimes, which makes it difficult to rescue children and youths from the world of crime. ${ }^{75}$ Moreover, the Report stressed the lack of adequate public security in peripheral areas, which foments the rise of death squads; the special military jurisdiction to which military officers are submitted once they commit a common crime, which collaborates to the impunity of death squads; and the poor police training, which 'often confuses violence with force'. ${ }^{76}$

At the time of the event in Candelária, an artist used to do social work with street children in that region. Nowadays, Ms. Yvonne Bezerra de Mello runs a non-governmental organisation in Rio de Janeiro whose main activity is to assist poor children. ${ }^{77}$ In 1997, Ms. Bezerra de Mello was interviewed and talked about her experience working with street children in Rio. According to her, street children have the same profile in relation to family relationships: 'they have never met their fathers and they hate their mothers, because mothers

74 IACHR. Report on the situation of Human Rights in Brazil. Chapter III: Police violence and impunity, \$40. Sep. 29, 1997, available at http:// www.cidh.oas.org/countryrep/brazil-eng/chaper\%203.htm, last visited July 8, 2010.

75 IACHR. Report on the situation of Human Rights in Brazil. Chapter V: Violence against minors, $\$ 20$, Sep. 29, 1997, available at: http:// www.cidh.oas.org/countryrep/brazil-eng/chaper $\% 205 \% 20$.htm, last visited July 8, 2010.

76 IACHR. Report on the situation of Human Rights in Brazil. Chapter V: Violence against minors, $\$ 20$, Sep. 29, 1997, available at: http:// www.cidh.oas.org/countryrep/brazil-eng/chaper\%205\%20.htm, last visited July 8, 2010. Referring to the special military jurisdiction afforded by military officers in Brazil, Leonardo Chusán observed: 'This system has been set up so that when military police officers are tried for alleged crimes, they normally are taken before special military courts rather than civilian panels. Military courts are notoriously known to be much more lenient on the part of their officers than civilian courts.' The Council on Hemispheric Affairs (COHA). 16 Years After Candelária Massacre Impunity and Death Squads Still Roam Brazil Streets. COHA's Research Associate Leonardo Faria Chusán, July 24, 2009, available at www.coha.org, last visited July 8, 2010.

77 See: www.projetouere.org.br. 
remind them of suffering and torture'. ${ }^{78}$ The social activist goes on to explain that 'usually, when a child runs away from home, it happens in a moment when he or she achieved the limit of supporting hunger and bad-treatment. ${ }^{79}$ Although affirming that, 'once on the streets, boys and girls tend to behave alike on their fight for survival', Ms. Bezerra de Mello observes a gender difference concerning the reason why children go to the streets. According to her experience, 'girls run away from sexual abuse committed against them by their family members. There are also cases of girls who have been sent away from home once they got pregnant. ${ }^{90}$

In relation to the characteristics of communities from where these children originally come, there is also a common pattern, according to Ms. Bezerra de Mello, which is violence. These are 'extremely violent communities, totally dominated by drug-trafficking, where there are barbaric deaths everyday; no silence, since shouting is constant; poor levels of comprehension and almost no love.' Once on the streets, children become addicted to glue, because it alleviates the hunger, and often they move on to other drugs as well. Considering the fact that addiction treatments are tremendously expensive, it is unlikely that any of these children will ever get rid of drugs. Still according to Ms. Bezerra de Mello, the vast majority of street children have AIDS, and due to their state of poverty and abandon, they have no access to health services. ${ }^{81}$

Ms. Bezerra de Mello stressed the major role played by international organisations and media in bringing the Candelária's perpetrators to justice. ${ }^{82}$ She also revealed

78 BEZERRA DE MELLO, Yvonne. Interviewed by Joaquim Pinto and Nuno Leonel, Sep. 3, 1997, available at www.youtube. $\mathrm{com} /$ watch? $=\mathrm{N} 8 \mathrm{X} 2 \mathrm{rNh} 90 \mathrm{bw}$, [original in Portuguese, translated by the author], last visited Aug. 1, 2010.

79 BEZERRA DE MELLO, Yvonne. Interviewed by Joaquim Pinto and Nuno Leonel, Sep. 3, 1997, available at www.youtube. $\mathrm{com} /$ watch? $=\mathrm{N} 8 \mathrm{X} 2 \mathrm{rNh} 90 \mathrm{bw}$, [original in Portuguese, translated by the author], last visited Aug. 1, 2010.

80 BEZERRA DE MELLO, Yvonne. Interviewed by Joaquim Pinto and Nuno Leonel, Sep. 3, 1997, available at www.youtube. $\mathrm{com} /$ watch? $\mathrm{v}=\mathrm{N} 8 \mathrm{X} 2 \mathrm{rNh} 90 \mathrm{bw}$, [original in Portuguese, translated by the author], last visited Aug. 1, 2010.

81 BEZERRA DE MELLO, Yvonne. Interviewed by Joaquim Pinto and Nuno Leonel, Sep. 3, 1997, available at www.youtube. $\mathrm{com} /$ watch? $\mathrm{v}=\mathrm{N} 8 \mathrm{X} 2 \mathrm{rNh} 90 \mathrm{bw}$, [original in Portuguese, translated by the author], last visited Aug. 1, 2010.

82 Concerning the inefficiency of the judicial system in Brazil, Human Rights Watch acknowledged a 'notable example of the failure of Brazilian authorities to protect witnesses of police violence in the case of Wagner dos Santos.' The boy was a street child who survived the Candelária massacre. He became a key witness to the that an average of $10 \%$ of street children will ever leave the streets, and admitted that the ones who remain on the streets will either die or be arrested. Finally, she emphasised the context of social injustice in Brazil, 'a country where rich and poor face accountability differently', and concluded on the reality of street children in Brazil:

The lives of street children and youths are very sad. There are no dreams or perspectives. There are no objectives, morals or codes of conduct. There is promiscuity all around. What are left are hunger, violence and hate. Hate from everyone who look at them wishing them to die, but who are incapable of doing anything to help improving their existences. ${ }^{83}$

More than ten years have elapsed since this interview. The reality of street children in Brazil, however, has not changed. There is also another important point raised by Ms. Bezerra de Mello supporting the view that poverty goes beyond the question of income. The interview indicated that there are many more poor children than street children in Brazil. The fact is that not every child living in extreme poverty leaves home to live on the streets of big cities. A child runs away from home when she or he achieved a limit of suffering which is broader than only a lack of money. To comprehend the reality of street children in countries such as Brazil and Guatemala, the issue of poverty must be analysed through different perspectives. According to Baxi, poverty must be understood not only in relation to material human needs, but also in relation to non-material human needs. Human needs encompass material, psychological and political needs. ${ }^{84}$ In homes where family relations are evolved in a context of deprivation and violence, children rarely have food, clothes and clean water, but they have absolutely no idea of what is protection and love.

criminal process, but was shot again by police officers while living under the protection of the state in the 'witness safe house'. Surviving to this second attack, he had to be assisted by Amnesty International to fly to another country in order to remain protected until the date of Candelária case trial. Human Rights Watch Report Police Brutality in Urban Brazil (1997) at \$32 and 33, available at www.hrw. org/legacy/reports/1997/brazil/, last visited July 8, 2010.

83 BEZERRA DE MELLO, Yvonne. Interviewed by Joaquim Pinto and Nuno Leonel, Sep. 3, 1997, available at www.youtube. com/watch? $\mathrm{v}=\mathrm{N} 8 \mathrm{X} 2 \mathrm{rNh} 90 \mathrm{bw}$, [original in Portuguese, translated by the author], last visited Aug. 1, 2010.

84 BAXI, Upendra. From human rights to the right to be human: some heresies. Ind. Int'l. Q., 1986. 


\section{DOES SOCIAL JUSTICE GO TO COURT?}

At the beginning of this decade, Mary Robinson, former United Nations High Commissioner for $\mathrm{Hu}$ man Rights, emphasised the need to advance economic, social and cultural rights by facing the challenge of 'empowering the poor'. ${ }^{85}$ In relation to this task, and particularly referring to the Organisation Human Rights Watch, Robinson emphasised that the International Human Rights Movement would have to move beyond its traditional focus on civil and political rights to increase its commitment with economic, social and cultural rights. ${ }^{86}$

In the last year of the decade, Amnesty International seems to respond to Robinson's claim. In the introduction to its 2010 Report, and after considering that 'across the globe, poverty is widening the justice gap, millions are denied health, food and housing (...)', Amnesty International concludes that 'massive abuse of economic, social and cultural rights is still a human rights crisis, and it too must be forced with legal commitments, not paper promises'. In relation to the legal adjudication of ESC rights, the NGO suggests that 'the law has two faces: it can punish, but it can also protect. ${ }^{987}$ Part of the speech of Claudio Cordone, Amnesty International Interim Secretary General, was also focused on economic, social and cultural rights:

Justice is not only about the right not to be tortured,
or to be free to express ones views without fearing
reprisal; justice is also being able to go to school, to
have access to clean water, and to obtain a decent health
care. To reduce poverty, to ensure access to education,
and proper maternal care are some of the Millennium
Development Goals; these are about people's human
rights, and they must be enforced by law. ${ }^{88}$

The foundation for establishing economic, social and cultural rights as judicially enforceable rights relies on the principle of human dignity, as Gauri and Brinks point out:

A life that achieves a full promise of human dignity requires, among other things, an escape

85 ROBINSON, Mary. Advancing Economic, Social, and Cultural Rights: The Way Forward, Human Rights Quarterly: 26, 872, 2004. 86 ROBINSON, Mary. Advancing Economic, Social, and Cultural Rights: The Way Forward, Human Rights Quarterly: 26, 872, 2004, at 869 .

87 Amnesty Int'l Report (2010). Available at http://therereport. amnesty.org, last visited Aug. 3, 2010.

88 Amnesty Int'l Report (2010). Available at http://therereport. amnesty.org, last visited Aug. 3, 2010. from premature death, the resources to withstand debilitating disease, the ability to read and write, and, in general, opportunities and freedoms unavailable in the midst of extreme poverty and deprivations. ${ }^{89}$

Taking into consideration the reality of poverty and examining the development of social action litigation in India, Baxi observed that 'in a context like India's one may not take rights seriously if one is unable to take suffering seriously." The author explains that 'social action litigation proceedings are writ proceedings for the enforcement of the fundamental rights (...) and that they compel judges and lawyers increasingly to take human suffering seriously. ${ }^{91}$ Social action litigation was justified by Justice Bhagwati, from India's Supreme Court with the affirmation that 'the newly emergent social and economic rights require new kind of enforcement', ${ }^{92}$ and Baxi reinforced this idea by highlighting that 'it is really the poor, starved (...) millions who need the court's protection for securing for themselves the enjoyment of human rights.' ${ }^{93}$

In this context, Brazil shares with India not only the reality of poverty which affects part of the population, but also the crescent development of social action litigation, as Hoffmann and Bentes observed after researching the enforcement of economic and social rights by the Brazilian Judiciary. The scholars concluded that, 'citizens have found in courts formal remedies to the inefficiencies of the health and education systems, and they have started using these remedies at a breathtaking rate'. ${ }^{94}$ Baxi supports the view that, in India, social ac-

89 GAURI, Varun and BRINKS, Daniel. M. Introduction: The Elements of Legalization and the Triangular Shape of Social and Economic Rights. In: GAURI, Varun and BRINKS, Daniel. M. (Eds.). Courting Social Justice: Judicial Enforcement of Social and Economic Rights in the Developing World. Cambridge: Cambridge University Press, 2008, at 1.

90 BAXI, Upendra. Taking Suffering Seriously: Social Action Litigation in the Supreme Court of India. In: BAXI, Upendra. Law and Poverty. Bombay: Tripathi, 1988, at 399.

91 BAXI, Upendra. Taking Suffering Seriously: Social Action Litigation in the Supreme Court of India. In: BAXI, Upendra. Law and Poverty. Bombay: Tripathi, 1988, at 399.

92 BAXI, Upendra. Taking Suffering Seriously: Social Action Litigation in the Supreme Court of India. In: BAXI, Upendra. Law and Poverty. Bombay: Tripathi, 1988, at 398.

93 BAXI, Upendra. Taking Suffering Seriously: Social Action Litigation in the Supreme Court of India, In: BAXI, Upendra. Law and Poverty. Bombay: Tripathi, 1988, at 391.

94 HOFFMANN, F., and BENTES, F. Accountability for social and economic rights in Brazil. In: GAURI, Varun and BRINKS, Daniel. M. (Eds.) Courting Social Justice: Judicial Enforcement of Social and Economic Rights in the Developing World. Cambridge: Cambridge University Press, 2008, at 141. 
tion litigation is a remedy to fight injustice and tyranny, because it compels 'a major institution of governance to take people's miseries seriously. ${ }^{95}$ The same approach can be taken in countries such as Brazil and Guatemala, where a background of deprivation and violence against the poor has dominated human rights concerns for so long.

Although assuming the justiciability of economic, social and cultural rights, some authors do not agree that claiming rights in Courts is the only or the best way of enforcement. Peter Uvin, for example, stressed that 'the impact of human rights in the behaviour of states was never exclusively a matter of judicial enforcement (...) since it has taken place through a variety of mechanisms. ${ }^{96}$ On the other hand, considering realities where political institutions cannot guarantee social justice, Uvin seems to justify the supranational enforcement of social justice in developing countries by recalling the principles of the rule of law and accountability. According to Uvin, 'accountability is precisely what distinguishes charity from claims (...) if claims exist, methods for holding those who violate claims accountable must exist as well. ${ }^{97}$ Therefore, in countries where political institutions uphold social injustices, the rule of law must be guaranteed by external agencies - notwithstanding being juridical or not.

In countries where the rule of law does not exist, where corruption and clientelism prevails, and where human rights are regularly violated both in high politics and low politics, it may be that only outside agencies can create, at least temporarily, the mechanisms required for the rule of law to emerge. ${ }^{98}$

Social justice considers the principle of 'freedom from want' in the context of human rights. ${ }^{99}$ The argument that particular situations can justify rights related

95 BAXI, Upendra. Taking Suffering Seriously: Social Action Litigation in the Supreme Court of India. In: BAXI, Upendra. Law and Poverty. Bombay: Tripathi, 1988, at 415.

96 UVIN, Peter. Human Rights and Development. Bloomfield: Kumarian Press, Inc., 2004, at 134.

97 UVIN, Peter. Human Rights and Development. Bloomfield: Kumarian Press, Inc., 2004, at 131.

98 UVIN, Peter. Human Rights and Development. Bloomfield: Kumarian Press, Inc., 2004, at 160.

99 The common Preamble to the two International Covenants emphasises the need to guaranteeing peoples' freedom from want, which can only be achieved by the enjoyment of economic, social and cultural rights. International Covenant on Civil and Political Rights and First Optional Protocol (ICCPR) and International Covenant on Economic, Social and Cultural Rights (ICESCR), G.A. Res. 2200, U.N. GAOR, $21^{\text {st }}$ Sess., U.N.Doc. A/RES/2200 A, Dec. 16, 1966. to social justice being claimed in courts is repeated by Gauri and Brinks, who define social and economic rights as 'claims to change the rules that govern the production and distribution of basic economic and social goods. ${ }^{100}$ The authors defend the judicial enforcement of such rights, which represents the transformation of individual wishes into legal demands, if there are obstacles to prevent the adoption of policies able to guarantee the enjoyment of such rights. According to the scholars, 'political blockages, monitoring deficits and incomplete commitments' ${ }^{101}$ can be regarded as obstacles to the enforcement of social and economic rights, which could therefore justify the role of courts on supervising their application and distribution among the population.

\subsection{Taking an integrated approach to human rights:}

What could be observed in the judgement of the Inter-American Court in the case of street children executed in Guatemala, and especially in the concurring opinion expressed by judges Trindade and Burelli in the same case, was an example of what has been called an 'integrated approach to human rights' ${ }^{102}$ Following the decisions of the European Court of Human Rights, this approach is based on the idea that the enjoyment of social rights is a necessary condition to the protection of civil and political rights. ${ }^{103}$ Maintaining a 'holistic human rights conception', the integrated approach understands that social rights are as important as civil and political rights, and that the violation of the former may give rise to a breach of the latter. As a result, 'strong judicial

100 GAURI, Varun and BRINKS, Daniel. M. Introduction: The Elements of Legalization and the Triangular Shape of Social and Economic Rights. In: GAURI, Varun and BRINKS, Daniel. M. (Eds.) Courting Social Justice: Judicial Enforcement of Social and Economic Rights in the Developing World. Cambridge: Cambridge University Press, 2008, at 13.

101 GAURI, Varun and BRINKS, Daniel. M. Introduction: The Elements of Legalization and the Triangular Shape of Social and Economic Rights. In: GAURI, Varun and BRINKS, Daniel. M. (Eds.) Courting Social Justice: Judicial Enforcement of Social and Economic Rights in the Developing World. Cambridge: Cambridge University Press, 2008, at 13.

102 MANTOUVALOU, Virginia. Work and Private Life: Sidabras and Dziautas v Lithuania, European Law Review: 30(4), 573$585,2005$.

103 MANTOUVALOU, Virginia. Work and Private Life: Sidabras and Dziautas v Lithuania, European Law Review: 30(4), 573585, 2005. 
protection of civil rights will be of little relevance to individuals who live in extreme poverty' ${ }^{104}$ This approach represents a method of interpretation of human rights instruments that allows a 'permeability of norms', in the words of Craig Scott. ${ }^{105}$ Aiming to give effect to the doctrine of interdependence of human rights, this technique of interpretation means 'the openness of a treaty dealing with one category of human rights to having its norms used as vehicles for the direct or indirect protection of norms of another treaty dealing with a different category of human rights.' ${ }^{106}$ As a consequence, failures on the implementation of social rights can be assessed through petition procedures of civil and political rights. This alternative method of adjudication demonstrates that, despite being theoretically considered equally fundamental for the individual, the two categories of rights have different kinds of monitoring machinery in International Human Rights Law. ${ }^{107}$

The integrated approach to human rights has also been applied in the United Kingdom (UK). The UK Joint Committee on Human Rights expressed concern with the ICESCR on its Twenty-first Report of Session 2003-04. The UK Joint Committee acknowledged that 'the UK has accepted international treaty obligations to protect economic and social rights under the ICESCR, the European Social Charter and the Conventions of the International Labour Organisation. ${ }^{108}$ The UK Joint Committee also pointed out that, although the ICESCR has not been incorporated into domestic legislation, as had the European Convention through the Human Ri-

104 MANTOUVALOU, Virginia. Work and Private Life: Sidabras and Dziautas v Lithuania, European Law Review: 30(4), 573585,2005 , at 574 .

105 SCOTT, Craig. The Interdependence and Permeability of Human Rights Norms: Towards a Partial Fusion of the International Covenants on Human Rights. Osgoode Hall L.J, 27, 771, 1989. 106 SCOT'T, Craig. The Interdependence and Permeability of Human Rights Norms: Towards a Partial Fusion of the International Covenants on Human Rights. Osgoode Hall L.J, 27, 771, 1989, at 771. According to the UN official policy for human rights, and consistent with the view adopted by the World Conference on Human Rights in 1993, in Vienna, all human rights are indivisible, interdependent and interrelated. UNHCHR. What are human rights? Available at: www.ohchr.org/EN/Issues/Pages/WhatareHumanRights.aspx, last visited May 14, 2010.

107 MANTOUVALOU, Virginia. Work and Private Life: Sidabras and Dziautas v Lithuania, European Law Review: 30(4), 573 585,2005 , at 573 .

108 The International Covenant on Economic, Social and Cultural Rights, Joint Committee on Human Rights 21st Report of Sess. 2003-2004, Nov. 2, 2004, available at: www.publications.parliament.uk/pa/ jt200304/jtselect/jtrights/183/18305.htm, last visited July 8, 2010. ghts Act, the UK has an internationally binding obligation to comply with the terms of the Covenant. Reaffirming the view that 'no clear line of demarcation can be drawn between the substance of rights classified as civil and political, and those classified as economic, social and cultural', the UK Joint Committee observed that 'some measure of protection for economic and social rights is afforded by the primarily civil and political rights guaranteed under the Human Rights Act.' ${ }^{109}$

The UK Joint Committee mentioned as examples of an integrated approach that facilitates the adjudication of economic and social rights in the UK, the right to be free from inhuman and degrading treatment, which is codified in the European Convention and encompasses the ICESCR right to an adequate standard of living, as well as the rights to privacy, personal autonomy and physical integrity, which are enshrined in the European Convention and can therefore be recalled as a way to protect the right to health and to agency related to healthcare, according to the ICESCR. Furthermore, the UK Joint Committee observed that protection of property and access to education, which can be regarded as social rights, are guaranteed by the first protocol to the European Convention, and hence have been incorporated into UK law by the Human Rights Act. ${ }^{1{ }^{10}}$ Therefore, economic social and cultural rights in the UK are protected primarily through legislation, but there is also a chance to bring the matter to the concern of domestic courts in connection with one of the rights protected under the Human Rights Act.

\subsection{The optional protocol to the ICESCR:}

The Second World Conference on Human Rights, held in Vienna in 1993, was the forum chosen by the CESCR to discuss the creation of an individual-complaints mechanism to the ICESCR. ${ }^{111}$ As a reflection

109 The International Covenant on Economic, Social and Cultural Rights, Joint Committee on Human Rights 21st Report of Sess. 2003-2004, Nov. 2, 2004, available at: www.publications.parliament.uk/pa/ jt200304/jtselect/jtrights/183/18305.htm, last visited July 8, 2010, at 11.

110 The International Covenant on Economic, Social and Cultural Rights, Joint Committee on Human Rights 21st Report of Sess. 2003-2004, Nov. 2, 2004, available at: www.publications.parliament.uk/pa/ jt200304/jtselect/jtrights/183/18305.htm, last visited July 8, 2010, at $11-12$.

111 DENNIS, M. J and STEWART, D. P. Justiciability of Economic, Social and Cultural Rights: Should there be an International Complaints Mechanism to Adjudicate the Rights to Food, Water, 
of the historical differences between the two sets of rights since the Cold war, what was noticed during the debates was that States which had been part of the Soviet bloc insisted that States were bound to guarantee economic, social and cultural rights to its citizens, while western delegations maintained that judicial implementation of these rights "was both inappropriate and impracticable. ${ }^{112}$ Among the delegations favouring the adoption of a new protocol, the need to empower economic and social rights adjudication as a way to reaffirm their equal status in relation to civil and political rights was the main argument raised. By contrast, the claim that the rights enshrined in the ICESCR were vague and therefore unenforceable by law, as well as difficulties related to the allocation of resources and national disparities in economic development, were the major problems that would prevent the adoption of an optional protocol to the ICESCR, according to the delegations opposing it. ${ }^{113}$

Scholars who do not agree with the creation of an individual complaints procedure for the ICESCR tend to focus on the differences between the two sets of rights, arguing that such differences explain the fact that economic, social and cultural rights cannot have the same kind of supervisory mechanism as civil and political rights. Dennis and Stewart, for example, do not believe that 'a legally binding adjudicative mechanism would lead to a greater compliance by states with the ICESCR obligations'. ${ }^{114}$ By stressing the practical difficulties related to time and resources required to implement economic, social and cultural rights, the authors defend that, when it comes to the promotion of the ICESCR in their territories, states should enjoy a

Housing and Health? American Journal of International Law, 98, 462-515, 2004.

112 DENNIS, M. J and STEWART, D. P. Justiciability of Economic, Social and Cultural Rights: Should there be an International Complaints Mechanism to Adjudicate the Rights to Food, Water, Housing and Health? American Journal of International Law, 98, 462-515, 2004, at 479 .

113 DENNIS, M. J and STEWART, D. P. Justiciability of Economic, Social and Cultural Rights: Should there be an International Complaints Mechanism to Adjudicate the Rights to Food, Water, Housing and Health? American Journal of International Law, 98, 462-515, 2004, at 472-473.

114 DENNIS, M. J and STEWART, D. P. Justiciability of Economic, Social and Cultural Rights: Should there be an International Complaints Mechanism to Adjudicate the Rights to Food, Water, Housing and Health? American Journal of International Law, $98,462-515,2004$, at 466 . margin of appreciation, which is an area of discretion allowed to states often justified on the need to respect their sovereignty. ${ }^{115}$ On the other hand, part of the doctrine sees the lack of a judicial remedy for a violation of economic, social and cultural rights, as one of the principal weaknesses in the International Human Rights Regime. ${ }^{116}$ Alston strongly supports the view that the development of an international jurisprudence will help to clarify the ICESCR provisions related to the rights of education, health care, food and housing, by such way facilitating the application of the Covenant by domestic courts. According to Alston, there are advantages of a complaints procedure that make it more adequate than a reporting one, such as the fact that it creates public awareness on social justice issues by both, generating media attention and increasing the political concern of governments. Moreover, the focus on a particular case might persuade governments to guarantee the availability of local remedies to enforce economic and social rights. ${ }^{117}$

On 10 December 2008, the UN General Assembly (GA) unanimously adopted an Optional Protocol to the ICESCR, which was opened for signature in 2009. The protocol provides the Committee on Economic, Social and Cultural Rights (CESCR) competence to receive and consider individual communications. Article 2 of the Protocol states that 'communications may be submitted

115 DENNIS, M. J and STEWART, D. P. Justiciability of Economic, Social and Cultural Rights: Should there be an International Complaints Mechanism to Adjudicate the Rights to Food, Water, Housing and Health? American Journal of International Law, 98, 462-515, 2004, at 467. Explaining the use of the doctrine of the margin of appreciation in the international supervision of human rights, see CORRÊA, P.M., The Sovereignty of States in the Inter-American System for the Protection of Human Rights [A Soberania dos Estados no Sistema Interamericano de Proteção aos Direitos Humanos. 122p. Dissertação de Mestrado. Programa de Pós-graduação em Relações Internacionais da Universidade Federal do Rio Grande do Sul: Porto Alegre: UFRGS, 2010, available at http://www.lume. ufrgs.br/handle/10183/26912].

116 ALSTON, Philip. No Right to Complain About Being Poor: The Need for an Optional Protocol to the Economic Rights Covenant. In ASBJORN Eide \& JAN Helgesen (Eds.) The Future of Human Rights Protection in a Changing World: Fifty Years Since the Four Freedoms Address: Essays in Honour of Torkel Opsabl, Oslo: Norwegian University Press, 1991, at 79-100.

117 ALSTON, Philip. No Right to Complain About Being Poor: The Need for an Optional Protocol to the Economic Rights Covenant. In ASBJORN Eide \& JAN Helgesen (Eds.) The Future of Human Rights Protection in a Changing World: Fifty Years Since the Four Freedoms Address: Essays in Honour of Torkel Opsahl, Oslo: Norwegian University Press, 1991, 79-100, at 92. 
by or on behalf of individuals or groups claiming to be the victims of a violation of any of the economic, social and cultural rights set forth in the Covenant by the State Party. ${ }^{118}$ Article 6(2) allows six months to the State Party to submit to the CESCR written explanations on the matter and the remedy provided, while article $8(3)$ asserts that on the examination of communications, the CESCR might consult documentations elaborated from other bodies, including regional human rights systems. Article 9 regulates on the recommendations made by the CESCR as well as on the information on measures taken by the State Party, and article 11 highlights the procedures following information of grave or systematic violations by a State Party of any of the economic, social and cultural rights set forth in the Covenant. Article 13 asserts that States parties must guarantee that protective measures are afforded to individuals who exercise the right to communication in the light of the Protocol, whereas the possibility of international assistance and cooperation to implement the Covenant rights is stated in article 14. The State obligation to disseminate information about the Covenant, its Protocol and the recommendations made by the CESCR is codified in article 16. ${ }^{119}$

The Optional Protocol to the ICESCR entered into force on 5 May 2013, with 43 signatures and 10 ratifications. Guatemala signed the Protocol on 24 September 2009, and Brazil has not signed it yet. ${ }^{120}$

\subsection{The chain of poverty and violence:}

From a sociological point of view, the human capacity to love derives particularly from the relationship between mother and child. ${ }^{121}$ Not surprisingly, specialists indicate the links between the family background of street children and their own inability to feel compassion. In the words of Turner,

\footnotetext{
Young children who are brought up in violent and traumatic circumstances will themselves be unable to recognize the plight of others, and hence their capacity for sympathy will be obscured and weakened (...).
}

118 Optional Protocol to the International Covenant on Economic, Social and Cultural Rights. G.A.Res. 63.117, U.N.GAOR, 63 ${ }^{\text {rd }}$ Sess. U.N.Doc. A/RES/63/117, Dec. 10, 2008.

119 Optional Protocol to the International Covenant on Economic, Social and Cultural Rights. G.A.Res. 63.117, U.N.GAOR, 63 ${ }^{\text {rd }}$ Sess. U.N.Doc. A/RES/63/117, Dec. 10, 2008.

120 United Nations Treaty Collection Database. Available at http://treaties.un.org, last visited Sept. 4, 2013.

121 FROMM, Erich. The Art of Loving. London: Thorsons, 1957.
The entry of young children and teenagers into civil conflict and crime is a function of the structural impetus behind new wars - namely, high unemployment and the exclusion of uneducated and unskilled young people from the peace economy. Marginalized youth groups are not subject to the discipline of work, nor do they have any access to the world of consumption. They cannot form stable relationships that might result in normal family life, work and reproduction. In this sense, they are not citizens but underclass or surplus population. ${ }^{122}$

Regarding the Candelária massacre, not all of the children who were sleeping in front of the church were killed that night. Some of them survived. In 2000, in an event immortalized in the cinema by the film 'Bus 174', an armed young man had hostage a bus in Rio de Janeiro, threatening to shoot the passengers who remained as hostages for many hours. The police killed one of the hostages by mistake, as well as the hijacker. The perpetrator of the kidnapping was Sandro do Nascimento, one of the children who had survived the Candelária massacre in 1993. The film not only describes the background of violence and abandonment common in the lives of street children, but also reports the fact that the suffering of such children is ignored and they are often stigmatised by society as undesirable criminals. Becoming 'invisible kids', in the words of the documentary, these children are 'starved of social existence and of recognition', and the violence generated by them must be understood as 'a cry for help'. ${ }^{123}$ The inevitable relationship between deprivation and crime is thus demonstrated. So is the correlation between the rights protected by the two International Covenants of rights. According to the documentary, the phenomenon of 'social invisibility represents our incapacity to deal with dramas such as social exclusion. ${ }^{124}$

Awareness of social problems does not necessarily lead to action on it. ${ }^{125}$ In the same way, the recognition of economic, social and cultural rights as fundamental human rights that must be provided by the State to every human being does not necessarily lead to compliance

122 TURNER, Bryant. Vulnerability and Human Rights: essays on buman rights. Pennsylvania: The Pennsylvania State University Press, 2006, at 40-42.

123 Bus 174 (film): Brazil (2002), produced by Zazen Produções and written by José Padilha, language: Portuguese: $150 \mathrm{~min}$.

124 Bus 174 (film): Brazil (2002), produced by Zazen Produções and written by José Padilha, language: Portuguese: $150 \mathrm{~min}$.

125 COHEN, Stanley., and SEU, Bruna. Knowing enough not to feel too much: emotional thinking about human rights appeals. In BRADLEY, M.P., PETRO, P. Truth Claims: Representation and Human Rights. London: Rutgers University Press, 2008, 187-204. 
with the ICESCR. Nor will an individual complaints procedure upon the CESCR automatically change the miseries of millions of children who live in the streets of Brazil or Guatemala. However, in the field of human rights, where consensus and improvement are so difficult to achieve, the Optional Protocol to the ICESCR should be understood as an international attempt to discuss and enforce social justice, which shall not be disregarded.

\section{Conclusion}

This study has sought to explore the relation between poverty and violence by examining the debates of poverty as a violation of human rights and the possibilities of enforcement of economic, social and cultural rights. Based on a multi-dimensional definition of poverty, the indivisibility and interrelation of human rights has been exemplified through the case of street children in Guatemala and Brazil. Children who live on the streets lack all basic rights necessary to live in dignity as a human being. As a result, they not only tend to develop a violent behaviour against the society that excludes them, but they also become extremely vulnerable to violence committed by police authorities.

Social exclusion happens when society insists on denying the existence of real (but unpleasant) facts. Street children and their world of poverty and violence are realities that people tend to either ignore - pretending that they do not exist - or to exterminate, as it has been exemplified in the action of death squadrons. In short, to live without the right to exist is the very tragedy of street children. The enforcement of economic, social and cultural rights arises as a possibility to promote protection and empowerment to these little ones, providing them with opportunities to fight for themselves in the future - because is solely in the future that they are supposed to do so.

As it has been demonstrated by the two cases of extrajudicial execution of street children analysed, social justice must be promoted in order to guarantee protection of civil and political rights. Consequently, the rights set forth in the ICESCR must achieve a better level of compliance by States, which demands the development of international mechanisms of supervision and enforcement. By discussing the integrated approach to human rights and paying particular attention to the su- ffering of poor and abandoned children, I agree with Philip Alston and others to support the view that the Optional Protocol to the ICESCR must be welcomed by the international community as a valuable attempt to fight poverty and enhance supranational mechanisms of state accountability.

\section{References}

ALSTON, Philip. No Right to Complain About Being Poor: The Need for an Optional Protocol to the Economic Rights Covenant. In ASBJORN Eide \& JAN Helgesen (Eds.) The Future of Human Rights Protection in a Changing World: Fifty Years Since the Four Freedoms Address: Essays in Honour of Torkel Opsabl. Oslo: Norwegian University Press, 1991, 79-100.

Amnesty Int'l Campaign Journal UK. On the streets, Issue 94, March/April 1999.

Amnesty Int'l Newsletter. Brazil: Child victims of killing and cruelty, Vol. XX, N. 9, Sep. 1990.

Amnesty Int'l Newsletter. Guatemala: children abused by police, Vol. XX, N. 8, Aug. 1990.

Amnesty Int'l Report 2010. Available at http:/ / therereport.amnesty.org, last visited Aug. 3, 2010.

Amnesty Int'l. Guatemala: extrajudicial executions and buman rights violations against street children. London: International Secretariat, July 1990.

BAXI, Upendra. Taking Suffering Seriously: Social Action Litigation in the Supreme Court of India. In: BAXI, Upendra. Law and Poverty. Bombay: Tripathi, 1988, 399.

BAXI, Upendra. From human rights to the right to be human: some heresies. Ind. Int'l. Q., 187, 1986.

BEZERRA DE MELLO, Yvonne. Interviewed by Joaquim Pinto and Nuno Leonel, Sep. 3, 1997 available at www.youtube.com/watch? $=\mathrm{N} 8 X 2 \mathrm{rNh} 90 \mathrm{bw}$, [original in Portuguese, translated by the author], last visited Aug. $1,2010$.

Bus 174 (film): Brazil (2002), produced by Zazen Produções and written by José Padilha, language: Portuguese: $150 \mathrm{~min}$.

CESCR. Statement on Poverty and the ICESCR. 25th sess., at 1, U.N. Doc. E/C.12/2001/10, 2001. 
CESCR. The Maastricht Guidelines on Violations of Economic, Social and Cultural Rights. 24th Sess., U.N. Doc. E/C.12/2000/13, 2010.

COHEN, Stanley. Seu, Bruna. Knowing enough not to feel too much: emotional thinking about human rights appeals. In BRADLEY, M.P., PETRO, P. Truth Claims: Representation and Human Rights. London: Rutgers University Press, 2008, 187-204.

DENNIS, M. J and STEWART, D. P. Justiciability of Economic, Social and Cultural Rights: Should there be an International Complaints Mechanism to Adjudicate the Rights to Food, Water, Housing and Health? American Journal of International Law, 98, 462-515, 2004.

FROMM, Erich. The Art of Loving. London: Thorsons, 1957.

GAURI, Varun and BRINKS, Daniel. M. Introduction: The Elements of Legalization and the Triangular Shape of Social and Economic Rights. In: GAURI, Varun and BRINKS, Daniel. M. (Eds.). Courting Social Justice: Judicial Enforcement of Social and Economic Rights in the Developing World. Cambridge: Cambridge University Press, 2008.

Human Rights Watch. Brazil: Curb Police Violence in Rio, São Paulo: extrajudicial killings undermine public security, (Dec. 8, 2009), available at www.hrw.org/americas/brazil, last visited Aug. 3, 2010.

Human Rights Watch. Universal Periodic Review of Guatemala: Police abuses, May 4, 2008, available at www.hrw. org/americas/guatemala, last visited Aug. 3, 2010.

I/A Court H.R. "Case of the Street Children" Villagran -Morales and others $v$ Guatemala, Preliminary Objections. Series C N. 32, 4, Sep. 11, 1997, available at www.corteidh.or.cr/docs/casos/articulos/series_32_ing.doc, last visited Nov. 14, 2009.

I/A Court H.R. "Case of the Street Children" Villagran -Morales and others v Guatemala, Merits, Series C N.63, 13 (Nov. 19, 1999) available at www.corteidh.or.cr/docs/ casos/articulos/seriec_63_ing.pdf, last visited July 21, 2010 .

I/A Court H.R. Case of the "Street Children" Villagran -Morales and others $v$ Guatemala, Concurring Opinion of Judges Cançado Trindade and Abreu Burelli, Series C N. 63, 1, Nov. 19, 1999, available at www.corteidh.or.cr/ docs/casos/votos/vsc_cancadoabreu_63_ing.doc, last visited Nov. 14, 2009.
IACHR. Report on the situation of Human Rights in Brazil. Chapter V: Violence against minors, Sep. 29, 1997, available at: http://www.cidh.oas.org/countryrep/brazil-eng/ chaper $\% 205 \% 20$. htm, last visited July 8, 2010.

International Covenant on Economic, Social and Cultural Rights. Joint Committee on Human Rights 21st Report of Sess. 2003-2004, Nov. 2, 2004, available at: www.publications.parliament.uk/pa/jt200304/jtselect/ jtrights/183/18305.htm, last visited July 8, 2010.

LADERCHI, Caterina Ruggeri, SAITH, Ruhi and STEWART, Frances. Does it Matter that we do not Agree on the Definition of Poverty? A Comparison of Four Approaches. Oxford Development Studies, 31:3, 243, 2003.

Limburg Principles on the Implementation of the ICESCR. Human Rights Quarterly, 9, 122-135, 1987.

MANTOUVALOU, Virginia. Work and Private Life: Sidabras and Dziautas v Lithuania, European Law Review: 30(4), 573-585, 2005.

Optional Protocol to the International Covenant on Economic, Social and Cultural Rights. G.A.Res. 63.117, U.N.GAOR, 63 ${ }^{\text {rd }}$ Sess., U.N.Doc. A/RES/63/117, Dec. 10, 2008.

ROBINSON, Mary. Advancing Economic, Social, and Cultural Rights: The Way Forward. Human Rights Quarterly: 26, 872, 2004.

SCOT'T, Craig. The Interdependence and Permeability of Human Rights Norms: Towards a Partial Fusion of the International Covenants on Human Rights. Osgoode Hall L.J, 27, 771, 1989.

SEN, Amartya. Development as Freedom. Oxford: Oxford University Press, 1999.

STEINER, Henry, ALSTON, Philip and GODMAN, Ryan. International Human Rights in Context: Law, Politics and Morals. 3rd edition. Oxford: Oxford University Press, 2008.

The Cocoyoc Declaration. International Organization. Vol. 29, n. 3, 893. International Responses to Technology, University of Wisconsin Press, summer 1975, available at http://websie.eclac.cl/mmp/doc/ Cocoyocdeclaration1974.pdf.

The Council on Hemispheric Affairs (COHA), 16 Years After Candelária Massacre Impunity and Death Squads Still Roam Brazil Streets, COHA's Research Associate Leonardo Faria Chusán, July 24, 2009, available at www.coha. org, last visited July 8, 2010. 
TURNER, Bryant. Vulnerability and Human Rights: essays on buman rights. Pennsylvania: The Pennsylvania State University Press, 2006.

UNHCHR. Claiming the Millenium Development Goals: $A$ Human Rights Approach, 2008.

UNHCHR. What are human rights? Available at: www.
ohchr.org/EN/Issues/Pages/WhatareHumanRights. aspx, last visited May 14, 2010.

United Nations Treaty Collection Database. Available at http:/ / treaties.un.org, last visited Sept. 4, 2013.

UVIN, Peter. Human Rights and Development. Bloomfield: Kumarian Press, Inc., 2004. 
Para publicar na Revista de Direito Internacional, acesse o endereço eletrônico www.rdi.uniceub.br ou www.brazilianjournal.org.

Observe as normas de publicação, para facilitar e agilizar o trabalho de edição. 